\title{
"Da fervorosa religião à geração de camisinhas nas mãos...": narrando uma juventude interiorana
}

\author{
Jefferson Adriã Reis ${ }^{1}$ \\ Universidade Federal de Rondonópolis \\ Márcio Alessandro Neman do Nascimento ${ }^{2}$ \\ Universidade Federal de Rondonópolis \\ Thiago Cardassi Sanches 3 \\ Universidade Federal de Mato Grosso \\ Moisés Lopes 4 \\ Universidade Federal de Mato Grosso
}

Resumo: A narrativa de história de vida busca a reconstrução e a análise de experiências singulares a partir de um engendramento coletivo de um período sócio-histórico-político e cultural localizado. O presente artigo investe na problematização de uma narrativa de uma história de vida de um jovem que compartilhou suas experiências relacionadas à vivência da homossexualidade masculina em uma região interiorana do estado do Paraná. A construção teórico-metodológica se formulou em uma entrevista transcrita e posteriormente analisada a partir de uma perspectiva pós-estruturalista dos estudos das produções de subjetividades, gêneros e sexualidades. Nesta pesquisa, buscamos, em um processo polifônico de análise, problematizar questões pertinentes que surgiram nas falas do participante e que se relacionam à sua composição de jovem homossexual e ao seu posicionamento de sujeito perante a macropolítica em intersecção com a micropolítica do desejo.

Palavras-chave: história de vida; homossexualidade; vida interiorana.

\footnotetext{
${ }^{1}$ Licenciado em Letras (Português) pela Universidade Federal de Mato Grosso (UFMT/Rondonópolis). Graduando em Psicologia pela Universidade Federal de Rondonópolis (UFR). Membro do LEPSI/UFR.

2 Psicólogo. Professor adjunto do curso de Psicologia da Universidade Federal de Rondonópolis (UFR). Coordenador do Laboratório Esquizoanalista de Produção de Subjetividades e(m) Interseccionalidades (LEPSI/UFR). Membro do Núcleo de Antropologia e Saberes Plurais (NAPlus/ICHS/UFMT).

3 Doutor em Estudos de Cultura Contemporânea pela Universidade Federal do Mato Grosso (UFMT). Mestre em Comunicação pela Universidade Estadual de Londrina (UEL). Graduado em Comunicação Social/Publicidade e Propaganda (Pitágoras) e em Turismo pela Universidade Estadual do Paraná (UNESPAR). Membro do LEPSI/UFR.

4 Graduação (2002) e mestrado (2005) em Ciências Sociais pela Universidade Estadual de Londrina, doutorado em Antropologia Social (2010) Universidade de Brasília, Pós-Doutorado (2018) em Antropologia Social pela Universidade Federal de Santa Catarina. Professor do Departamento de Antropologia e do Programa de Pós-Graduação em Antropologia Social Universidade Federal de Mato Grosso e coordenador do Núcleo de Antropologia e Saberes Plurais (NAPlus/UFMT).
} 


\title{
"From fervent religion beliefs to an entire generation with condoms at hands ...": narrating a countryside youth
}

\begin{abstract}
The life history narrative aims at the reconstruction and analysis of singular experiences based on a collective engendering of a localized socio-historicalpolitical and cultural period. This paper invests in problematizing a life history narrative of a young man who shared his perceptions related to the experience of male homosexuality in an interior region of the state of Paraná, Brazil. The theoreticalmethodological construction was formulated in a transcribed interview and later analyzed from a post-structuralist perspective of studies about production of subjectivities, genders, and sexualities. In this research, we seek, in a polyphonic analysis process, to problematize pertinent issues that arose in the participant's speeches related to his composition as a young homosexual and his position as a subject towards the macropolitics in intersection with the micropolitics of desire.
\end{abstract}

Keywords: life history; homosexuality; countryside life.

\section{"De la religión ferviente a la generación de condones en las manos ...": narrando una juventud campestre}

\begin{abstract}
Resumen: La narrativa de la historia de vida busca la reconstrucción y el análisis de experiencias únicas a partir de un engendramiento colectivo de un período sociohistórico-político y cultural localizado. Este artículo invierte en la problematización de una narrativa de la historia de vida de un joven que compartió sus vivencias relacionadas con la vivencia de la homosexualidad masculina en una región rural del estado de Paraná. La construcción teórico-metodológica se formuló en una entrevista transcrita y luego analizada desde una perspectiva postestructuralista de estudios sobre las producciones de subjetividades, géneros y sexualidades. En esta investigación buscamos, en un proceso polifónico de análisis, problematizar cuestiones pertinentes que surgieron en las declaraciones del participante y que se relacionan con su composición como joven homosexual y su posición como sujeto frente a la macropolítica en intersección con la micropolítica del deseo.
\end{abstract}

Palabras clave: historia de vida; homosexualidad; vida de campo. 
$\mathrm{E}$ ste artigo tem como objetivo levantar questões sobre a construção, conformação e vivência de subjetividades homossexuais masculinas a partir de "contextos interioranos" do país. Tal como apontado por Moisés Lopes (2016), a interioridade não pode ser pensada a partir de uma oposição simples e reducionista entre capital e interior, mas a partir de uma dinâmica relacional que leva em consideração diferentes elementos, tais como: os regimes de visibilidade e de invisibilidade; a gestão do segredo sobre as (homos)sexualidades; a construção de uma comunidade de iguais que aciona questões como a identidade, a violência e as resistências; e a elaboração de homonormatividades.

A narrativa de Marcos será o fio condutor que nos levará a analisar as questões apontadas, mas, antes de iniciarmos tal apresentação, é importante destacar que não tomamos, seguindo a tradição das Ciências Humanas, a narrativa como um evento que se esgota em si mesmo e nos dá acesso a uma subjetividade específica. Pelo contrário, partimos do princípio de que as narrativas de vida são reveladoras para os analistas, pois carregam em si questões sociais a respeito do grupo social ao qual o narrador faz parte e, com isso, expandem nossa compreensão sobre este grupo, como analisam Venan L. de Oliveira Alencar (2020) e Moisés Lopes (2016). O essencial é que nos baseamos na provocação desenvolvida por Claudia Fonseca (1999), de que “Cada caso não é apenas um caso" e de que a narrativa de Marcos, para ser completamente compreendida, tem que ser inserida no cerne de suas relações sociais, não se trata deste modo de um ser humano genérico, sem rosto.

\section{Narrando uma "vida interiorana"}

O primeiro encontro com o participante se deu ao acaso, em um fato marcante para ele - a primeira vez em que visitava um estabelecimento também frequentado por um público LGBT+. Eu5 nunca imaginaria que aquele acontecimento que marcou sua vida, de alguma forma, seria narrado em minhas entrevistas. Marcos ${ }^{6}$, amigo de um amigo do meu amigo, e outros colegas se encontraram em uma noite qualquer, agradável para estar com outras pessoas, em um bar onde eu estava presente. Chegou acompanhado pelo amigo do meu amigo, que o apresentou de maneira escrachada: "Olha, gente, esse é meu amigo lá da Igreja, não sou o único gay lá (risos), só que ele nunca nem beijou homem, já eu... (risos)”, e nesse instante, iniciaram-se as brincadeiras de que o novato, naquela noite iria beijar um outro homem, no mínimo. Já naquele momento, todos pareciam muito próximos a ele, oferecendo bebidas, contando como funcionava o lugar, apontando outros rapazes que lhes despertavam interesse e rindo de personagens típicos daquele bar. Marcos parecia muito mais assustado e tímido do que era esperado de um rapaz de sua idade. Marcos era de estatura baixa, branco, com pou-

\footnotetext{
5 É importante salientar que esta entrevista foi realizada pelo primeiro autor deste artigo, por isso haverá trechos de diário de campo em primeira pessoa do singular.

${ }^{6} \mathrm{O}$ nome Marcos se refere a um nome fictício escolhido pelo próprio participante no momento das entrevistas. De acordo com procedimentos éticos para pesquisas acadêmicas, foram respeitados os incisos constantes nas resoluções do Conselho Nacional de Saúde em que constava a autorização do registro das informações (áudio-gravadas e transcritas) e divulgações das entrevistas mediante o comprometimento do entrevistador em realizar pesquisa dentro dos moldes éticos e de manter o anonimato do colaborador, assim como constava o contato do pesquisador, da instituição de origem e do Comitê de Ética acionado.
} 
cos pelos no corpo, sem traços de barba, sorriso fácil, voz baixa, olhar infantilizado e tímido, vestido com boné e roupas de estilo teenager que lhe garantia uma aparência mais jovem do que a sua idade (aproximadamente vinte anos).

Lembro-me de ter conversado muito pouco e de ouvir suas respostas baixas e incompletas sobre a religião e sobre ser sua primeira participação no cenário daquele bar. Também me recordo de meus conselhos paternalistas, de que não desse ouvidos para as brincadeiras que lhe desagradavam, que as pessoas queriam "enturmá-lo" (era esse o motivo das brincadeiras). Eu dizia, ainda, que ele estava dirigindo sua moto Biz e, portanto, não precisava tomar bebida alcoólica do copo de todos que lhe ofereciam para parecer simpático, uma vez que ele não tinha o hábito de beber. Em resposta, ele havia me dito que estava um pouco assustado, que não conhecia ninguém e que isso era uma condição boa, pois não teria problemas com a visibilidade, porém, não queria ficar com o rapaz que os novos colegas estavam lhe apresentando, não sabendo como dizer não. Logo, Marcos virou a mascote daquela turma, como observei em outros momentos bem a posteriori, nos dispositivos de socialização de sexualidades LGBT+ que pesquisei - uma boate e um bar.

Nosso próximo encontro aconteceu na semana posterior à conversa no bar, em outro momento importante da vida de Marcos - o primeiro contato afetivosexual com uma pessoa do mesmo gênero, Vinícius (nome fictício), que evoluiu para um namoro. Marcos morava sozinho em um bairro mais afastado do centro da cidade, no entanto, não possuía a liberdade de uma pessoa que morava sem os pais. Esse fato ocorria porque integrantes da Igreja da qual era membro costumavam aparecer em sua residência sem avisá-lo, sendo que uma amiga da Igreja, que também trabalhava com ele, tinha a chave de sua casa e surgia sempre de repente.

O rapaz que Marcos conheceu, Vinícius, tinha quase a sua idade e morava em outro município, há 500 quilômetros de distância. Segundo Marcos, essa situação era proposital, para evitar encontrar, pela internet, pessoas conhecidas que pudessem denunciar sua homossexualidade. Vinícius veio de outro estado e se hospedou na casa do amigo de Marcos, que era amigo do meu amigo. Como naqueles filmes americanos escrachados sobre adolescentes, fui convidado, sem saber sobre a situação, a ir ao local onde o casal estava (para buscar a chave do carro de um colega) e quando adentrei a residência, acompanhado por conhecidos, vi que havia pela casa várias embalagens de camisinhas e um tubo aberto de lubrificante jogado no chão. Logo em seguida, encontrei-os abraçados (em posição de conchinha) em um sofá apertado. Eles pareciam envergonhados e assim também me senti, por isso me retirei do local em companhia dos outros.

Após os dois episódios descritos acima - lembrados e narrados -, voltei a reencontrar Marcos na boate da cidade. Na ocasião, ele parecia mais extrovertido e marcado pela cultura massificada de jovens gays da época: colares, pulseiras, camiseta psicodélica, boné e calça jeans cheia de recortes e detalhes. Alegre, festivo, cercado por pessoas, alterado por alguma bebida alcoólica e agitado por conta da música alta e de batida forte, Marcos veio me cumprimentar. Após algum tempo conversando, ele me perguntou sobre as entrevistas que eu estava realizando, então resolvi convidá-lo para ser participante (uma vez que procurava por alguém da idade dele). Contudo, eu disse que gostaria de explicar sobre o trabalho acadêmico em outra situação e ele concordou, então me passou seu celular e endereço para o possível primeiro agendamento da entrevista. 
Nessa conversa, também descobri que o possível participante havia mudado de residência e que estava dividindo apartamento com um amigo também homossexual. Marcos frisou que essa condição era importante para dividir residência, pois gostaria de se sentir à vontade na própria casa, em relação a sua sexualidade. Inicialmente, foi difícil estabelecer datas com ele, por conta do trabalho durante o dia e da faculdade no período noturno, portanto as entrevistas só seriam possíveis se ocorressem nos finais de semana, quando ele não tivesse compromisso.

Nas semanas subsequentes, surgiram oportunidades para que nos encontrássemos, mas quase sempre Marcos cancelava, pois "precisava ir a um churrasco ou festa”. Quando comecei a procurar por outro participante, o rapaz me ligou e agendou para o dia seguinte a entrevista, que se estendeu para dois dias consecutivos (sábado e domingo), por conta da quantidade de tempo de gravação e do cansaço de participante e pesquisador. Nos encontros, que aconteceram em tardes extremamente quentes e abafadas, fui recepcionado alegremente por Marcos em um apartamento que lembrava um lugar sacro, pois na entrada da residência se avistava um altar com diversas estatuetas de anjos, santos e imagens da espiritualidade Oriental. Esse altar pertencia ao colega de Marcos e se encontrava em meio à bagunça típica de uma república estudantil.

$\mathrm{O}$ tom das nossas conversas se estabeleceu em um ritmo bastante próprio e descontraído, com uma configuração típica de interlocuções de jovens. Embora Marcos quisesse dar um caráter de seriedade aos diálogos, às vezes tecia comentários irreverentes, como, por exemplo, quando narrou a situação em que estava entrando na casa de amigas da Igreja em que congregava e um "jovem homossexual" flertou com ele. Sobre essa situação, que envolvia desejo, preconceito e as maneiras possíveis de encará-los, Marcos contou: "Daí, eu entrei e as meninas brincaram comigo que ele estava se exibindo para mim e que ele era gay, mas era legal. Vê se pode ser gay e legal? (risos). Tudo que eu queria, gay e legal”. Entretanto, o medo de se expor perante as amigas fez com que Marcos apenas investigasse a vida do jovem (por quem também se interessou). Naquele momento, o temor de ser descoberto e difamado na Igreja e na família interditou a possibilidade de uma maior interação com o rapaz desconhecido.

Ao longo da entrevista, Marcos se autodenominou homossexual, utilizando como critérios se relacionar com pessoas do mesmo gênero, apresentar desejos e vivências pautadas em um estilo homossexual de vida e sua própria aceitação:

\begin{abstract}
Primeiro, é o fato de minha aceitação, porque até então, antes da minha aceitação, eu não me considerava... Eu não sei se na definição geral poderia já ser, mas eu não me via como, então, para mim, a definição, o ponto que me fez... hum... ter essa posição de hoje falar que eu... hum... eu sou homossexual (verbaliza a palavra em um tom bem baixo de voz), a minha homossexualidade de hoje. Então, hoje ter relacionamento, amigos do meio, é, enfim, eu não correr dessa realidade, eu não correr desse fato que está acontecendo, então, é isso que eu acho que é o ponto. Então, a minha aceitação começou a vir depois que eu comecei a conviver com pessoas do meio assim como tive relacionamentos homossexuais.
\end{abstract}

O entrevistado completou dizendo que se considera uma pessoa assumida (em relação a sua condição homossexual):

O fator mais importante para mim de assumir a sexualidade é você aceitar e estar bem com essa situação, com aquilo que se está vivendo, então, assim, eu acho que isso é a aceitação principal. Agora eu acho assim, o fato de contar ou não contar, de não falar, é a exposição mesmo. Eu me considero assumido porque várias pessoas do meio sabem e tudo, o que acontece é que eu procuro não me expor a todo o momento e ter uma vida mais reservada, não a todos, a algumas pessoas mais próximas que não são minha família, mas que são mais próximos, são meus amigos, gradativamente 
alguns vão sabendo, mas sem exposição em massa, sem espalhar, sem exposição em massa mesmo.

Marcos me mostrou o apartamento e fotos de amigos. No entanto, ele me disse não ter fotos da infância pela condição de pobreza e por ser oriundo de um município rural, onde a família morou em um modesto sítio. As fotografias mostravam momentos de alegria e descontração, uma vez que quase todas eram imagens de churrascos e comemorações de amigos jovens LGBT+, homens gays cis e cursando alguma faculdade (aspecto valorizado pelo participante). Os amigos eram jovens entre 18 e 25 anos, alguns aparentemente identificados como LGBT+. Marcos parecia ser muito requisitado, comprometido e solidário com os amigos, talvez por conta de aprendizagens provenientes da dinâmica familiar e de características pessoais que facilitam a socialização, como o bom humor e o acolhimento.

$\mathrm{O}$ aspecto da vivência das dificuldades sociais da vida familiar (como baixa renda, baixa escolaridade - apenas o Ensino Fundamental) fez com que a família concordasse que Marcos continuasse morando na cidade sozinho, porque estudava e trabalhava desde os 17 anos. O estilo simples e batalhador da família e os valores de solidariedade parecem ter corroborado para que Marcos construísse características pessoais importantes para o enfrentamento da vida. $\mathrm{O}$ participante tinha uma irmã mais velha e casada e um irmão adotivo mais novo, que moravam em um sítio da família. Marcos visitava sua família de origem muito esporadicamente, com a justificativa de que os estudos tomavam o seu tempo, assim como o trabalho e os afazeres domésticos. Ele também se queixava de cansaço e reforçava a necessidade de viver a homossexualidade mais livremente, longe do controle familiar e sem sentir medo de que seus pais descobrissem.

Em se tratando de como percebeu que se sentia atraído por pessoas do mesmo gênero, Marcos relatou que isso ocorreu aproximadamente aos oito anos, quando admirava conscientemente a beleza dos homens. Aos 15, foi o período em que se tornou mais intensa a luta para reprimir a atração e o desejo por pessoas do mesmo gênero, pois, como ele me disse: "eu tentei evitar, a todo custo, a ponto de... é, não pensar na situação em si, até eu sentir a atração, mas em seguida eu consegui não pensar na situação em si”.

Marcos revelou que sua família não sabia de suas práticas e vivências afetivosexuais, mas que existiam cobranças por parte de seus pais:

\footnotetext{
Cobrança do padrão, que é você constituir família, casar... hum... ter filhos, né, e isso é uma cobrança grande, por conta dos pais que querem... hum... netos, eles já têm netos por parte da minha irmã, mas eles sempre cobram, dizendo: Quando que você vai se casar? Quando vamos ter netos? Esse... esse tipo de cobrança, né. Ou cobrança até assim, né, simples, como: Quem que é a sua namorada? Esse tipo de cobrança que, por enquanto, eu consigo relevar e contornar, mas vai chegar um ponto que não vai ter como contornar essa situação, sem contar a verdade, sem se abrir e falar o que realmente é.
}

Diante disso, verbalizei que ele não parecia estar preparado para lidar com a reação dos pais e ele argumentou dizendo que dependeria do modo como ele lidaria com a situação, pois acreditava que seus pais teriam dificuldade para entender tais questões. Completou afirmando que os pais tinham uma visão pejorativa e distorcida das questões que envolvem as homossexualidades, principalmente por conta da doutrina evangélica e da cultura massificada difundida pela mídia e pelo senso comum. $\mathrm{O}$ próprio participante analisou que a religião atingia mais fortemente sua família, porque o baixo grau de instrução e a devoção à religião são fatores que não permitem que seus familiares se apropriem de uma visão mais compreensiva a respeito das homossexualidades. 
Em relação à vivência de sua sexualidade e à revelação para a família, Marcos entrevia a seguinte resolução para esse impasse:

\begin{abstract}
Eu acredito que... não o que dificulta, mas é que eu não estou preparado ainda para receber a reação deles, porque é difícil prever a reação que eles vão ter, mas eu acredito que eles não aceitariam de forma alguma. (...) Não digo que não aceitariam, hum, ops, não digo que aceitariam mais para frente, eles até não aceitariam também da mesma forma. Eu acredito também que mais para frente eles estejam pensando da mesma forma, mas o que teria mudado seria eu, eu estaria mais pronto para receber essa não aceitação deles, né? Hoje eu acho que não estou preparado para isso ainda, eu acredito. (...) se eles descobrissem mesmo, não tendo para onde correr, eu confirmaria e tentaria da melhor forma possível de eu estar convivendo. O primeiro passo seria esclarecer a eles do que que é a homossexualidade, né? Porque eles têm o conceito totalmente errado, até eles imaginam que o homossexual, ou amanhã ou depois, chegar em casa e falar que eu sou gay, eles vão ter uma visão meio distorcida do que é.
\end{abstract}

Marcos acreditava que seus familiares desconfiavam de sua condição homossexual, pois sempre lhe cobravam namoradas. Diante disso, a estratégia que utilizava para se manter "desacreditável” (GOFFMAN, 1988) e permanecer na invisibilidade era flertar e beijar meninas da região rural quando visitava a família, de maneira a embaralhar os códigos que poderiam lhe atribuir uma identificação homossexual.

No entanto, em concomitância à tentativa de invisibilidade, Marcos se destacava pelo uso de acessórios que o caracterizava, pelo senso comum, como nãoheterossexual, tais como brincos, correntes, pulseiras, roupas fashions, entre outros detalhes. Sobre o brinco, o participante disse que a família não aprovou e se posicionou por meio do silêncio, e quando questionou agoniado sua irmã sobre tal situação, a resposta foi:

\begin{abstract}
que para ela não tinha problema, mas que brinco não tinha a ver com ser gay, e se o filho dela um dia furasse a orelha ela num ia ligar, mas uma coisa não podia ser, que era ser gay (risos). Aliás, foi diferente, ela disse que o importante era ser homem, ela não usou a palavra gay, mas sim, não deixar de ser homem (risos). (...) me deu um nó na garganta, me senti muito mal, e daí eu fiz de conta que não era comigo. Concordei com ela, mas fiquei chateado. Mas me deu vontade de contar para ela, mas daí eu respirei fundo e disse que para mim mesmo que era melhor não, pois eu ainda não me sinto preparado para estar falando para nenhuma das pessoas da minha família, mas foi um dos momentos que eu fui levado a quase contar.
\end{abstract}

A construção social das (homos)sexualidades, marcada pelo discurso religioso, é muito evidente nas falas de Marcos, uma vez que esses enunciados funcionam como um dispositivo de controle sobre as sexualidades (corpos e desejos), enunciados estes presentes em sua vida desde o momento em que veio ao mundo. Os atravessamentos de subjetivação e o assujeitamento da família aos enunciados da religião fizeram com que Marcos também interditasse os desejos e as expressões homoeróticas. O participante compreendia e aceitava que a Igreja em que congregava (uma doutrina Evangélica Pentecostal radical) pregava uma visão pejorativa e excludente das homossexualidades. Entretanto, a religião havia se tornado um dispositivo de controle muito eficiente (disciplinarização e assujeitamento) para Marcos, pois, mesmo quando a família foi para outro município, ele continuou a frequentar a Igreja, uma vez que os laços afetivos e a socialização também eram fortalecidos nesse contexto:

A Igreja sim... ela tem uma visão totalmente contrária nesta... questão, só que quando eu tô... como eu também falei... eu queria... eu também não queria pensar aquilo, eu não queria sentir aquilo. Então, para mim, aquilo não era... ruim eles não aceitarem, porque nem eu mesmo aceitava. Então, o fato de eles não aceitarem, num..., não..., para mim na época era normal, porque até mesmo eu não aceitava. 
No que diz respeito à relação entre visibilidade e contexto de trabalho, Marcos assumiu uma postura neutra, pois acreditava que não era necessário expor sua sexualidade, assim como, durante muito tempo, não se considerou homossexual e não entendia o processo e construção de seus desejos homoeróticos. $\mathrm{Na}$ escola, também não teve nenhum problema relacionado à visibilidade da condição homossexual, expondo:

\begin{abstract}
[que] foi uma coisa assim, em todo o momento, mesmo quando eu percebi... foi até tranquilo, porque eu não me denominava homossexual, assim, eu sentia alguns desejos, mas era algo que eu não aceitava, então, eu não me denominava homossexual, então, eu não acredito que eu tive, hum, que eu tive normal, mas no... no... nesse período, eu não ficava com garotos, digamos que foi normal, não foi [silêncio], como eu posso dizer? Até no período escolar eu tive namoradas, esse tipo de coisa [silêncio], foi mais ou menos isso.
\end{abstract}

O desejo homoerótico se manifestou mais fortemente em Marcos quando estava morando sozinho e começou a trabalhar na área da informática, aos 18 anos. A facilidade de informações por meio de produtos mercadológicos e conteúdos homoeróticos disponibilizados na internet, concomitante à garantia do anonimato, fez com que o participante ingressasse no "mundo homoerótico" oferecido pelas tecnologias e redes de comunicação.

$\mathrm{Na}$ época em que ingressou na faculdade, quando já havia assumido para si sua homossexualidade, as piadas e práticas sociais homofóbicas dos colegas de curso tinham uma conotação e uma representação que lhe traziam mal-estar, uma vez que eram direcionadas às suas vivências e gostos, como relata:

\begin{abstract}
Olha, o que acontece, no meio sempre tem umas brincadeiras homofóbicas, uma piada... uma... Enfim, sempre tem uma coisa... relacionado à homossexualidade. Eu particularmente não participo, não participo da mesma brincadeira, mas também não critico, até... para manter a... como que eu poderia dizer... para evitar que eles percebam, então quando tem uma piada eu não defendo, mas também não compartilho da brincadeira, até porque vai contra a... o que eu acho correto, né? Então, eu não participo, mas também não chegou a defender.
\end{abstract}

Ainda sobre o contexto universitário, Marcos analisou os prós e contras de se assumir homossexual perante os colegas, dizendo:

\begin{abstract}
no caso da faculdade, teve um caso de uma garota... vir falar comigo, coisa do tipo... jogar indireta... paquerar, esse tipo de coisa. Então, eles sabendo evitaria, situações assim... mas eles sabendo, com certeza teria muito preconceito, então, teria um lado bom e um lado ruim da história. No caso, como eles não sabem... como que eu posso dizer... Eu tenho uma vida... hum... uma vida reservada, né? Eles nunca vão saber a festa, o ambiente que eu vou, por exemplo, eu não comento... Se eu for para uma boate gay, eu não vou chegar comentando com eles. Às vezes é ruim, porque você quer se comunicar, você quer conversar, mas também eu não vou sofrer o preconceito, por parte deles, né? Então, tudo tem essas medidas, né?
\end{abstract}

O modo de subjetivação atravessado pelo discurso religioso foi marcante para que Marcos moldasse o seu estilo de vida nos diversos segmentos sociais. Uma dessas marcas foi estabelecer dois mundos paralelos: um mundo familiar, com amigos da Igreja, com disciplina, assujeitamento e programação da vida: "A pessoa deveria crescer, casar, ter filhos... É esse parâmetro que eles têm, né? É o parâmetro da cobrança social que eles têm muito forte, que é o homem crescer, casar com uma mulher e ter filhos"; e um outro mundo, caracterizado por acontecimentos marcados pelo acaso, possibilidades, incertezas, enfrentamentos e construções de estilos de existência e expressão de diversos olhares para as questões emergentes das práticas sociais. Um exemplo disso segue na narrativa de Marcos: 
Eu tenho tantos amigos do meio... do meio LGBT, de frequentar ambientes gays, $e$ tenho amigos também que não sabem de mim, que não sabem... Consigo, hoje, conviver mais com meus amigos que são do meio, até pela facilidade de sair junto, de você não precisar estar escondendo sempre o que você é, e por isso eu convivo mais com amigos que são do meio e que frequentam o meio LGBT. Mas tenho amigos héteros ainda, que, às vezes, a gente sai para algum barzinho e coisas do tipo.

Marcos acreditava que alguns amigos da Igreja se afastariam dele caso revelasse sua condição homossexual, pois condicionavam a imagem da pessoa LGBT+ com o pecado, com a anormalidade e com o desvio. O conjunto das narrativas distribuídas durante a entrevista me levou a perceber que a Igreja que Marcos frequentava agia de maneira intimidadora, instalando uma sensação de vigilância, condição que fez com que o rapaz se afastasse das atividades religiosas, como bem diz:

Então, o fato de não frequentar, foi o fato de discordar com algumas coisas que são praticadas... A partir do momento em que eu estava discordando com o que estava sendo passado ali, por opção eu decidi não frequentar mais, a deixar de estar frequentando. Mas é bem por isso mesmo, é por discordar do ponto de vista deles.

Além disso, existiu um conjunto de fatores que levou Marcos a se afastar da instituição religiosa, não somente pelo desconforto que poderia vir a sofrer pelas tentativas penitentes de autocontrole do desejo homoerótico, mas também pela própria história de punição e desrespeito experienciados em outros momentos, como relatou:

Eu e essa amiga que trabalha comigo, ela era, aliás, ela frequenta a igreja ainda.
Como eu falei, eu conheci ela lá na Igreja. A gente estava trabalhando juntos, porque
ela também era obreira, e eu estava em uma salinha com ela e eu estava com dor nas
costas e ela foi estalar minhas costas, daí uma menina que tinha inveja da gente, pelo
posto de confiança que a gente tinha dentro da Igreja, foi e falou para o pastor que
nós estávamos transando. O pastor nem quis saber, marcou uma reunião chamando
todos os conselheiros, e nesse dia tinha outros pastores também, e na frente de todo
mundo começou a nos acusar, dizer que a gente estava em pecado. Ele acusava di-
zendo que sabia o que a gente tinha feito e que não adiantava negar. A gente tentou
falar que não era verdade e ele começava a gritar na frente de todos, dizendo que a
gente era resistente, que além de pecar não assumia, que não estávamos arrependi-
dos. E tinha mais um cara que queria tomar meu posto lá, que ajudou essa menina.
Foi um vexame, uma humilhação em público, sem direito a defesa, com os familiares
dela todos presentes, nossos amigos. Ah, daí um amigo nosso foi tentar defender e o
pastor falou que ele era cúmplice do pecado e quase colocou ele no meio da confusão,
daí ninguém se manifestou, nem a família dela, apesar de todos os nossos amigos e
da família dela saberem que era mentira esse fato. Foi horrível. Eu tinha um cargo
bom lá, eu coordenava os jovens, ajudava a organizar as festas dos homens, dos en-
saios com a banda, eu tinha um programa na rádio. Daí, a gente foi afastado, não
podia ser mais obreiro por um tempo, porque a gente tinha que servir de exemplo
perante todos, tínhamos que servir para as pessoas não fazerem isso. A gente só seria
ouvinte, de ficar no banco da Igreja. Mas depois a gente voltou, porque a gente fazia
as coisas funcionarem, a gente agitava os jovens e organizava tudo certinho.

A cena descrita acima demonstra como o discurso religioso produz saberes e verdades sobre as sexualidades, ou seja, uma scientia sexualis (FOUCAULT, 2005), que pratica estratégias de controle sobre os corpos e sobre as sexualidades dos frequentadores da Igreja, neste caso, procedimentos que incitam à confissão do suposto pecado e que recorrem às práticas sociais violentas vexatórias em público. Recorrendo aos estudos de Michel Foucault (1987: 228), encontramos que o espetáculo público da punição contra "criminosos" parece ter adquirido importância no início do século XIX; era dita como "uma cerimônia de suplício", na qual havia execração, humilhação e ofensas. Dessa maneira, Marcos foi impulsionado a assumir-se culpado e a servir como exemplo indulgente para que os frequentadores não ousassem desafiar a ordem social estabelecida. Na narrativa, 
Marcos parece ter sido usado como uma vítima do dispositivo da sexualidade somado à estratégia de assujeitamento do dispositivo religioso.

A punição para a cena narrada por Marcos foi dada de maneira drástica, mesmo que o suposto pecado tenha sido uma prática sexual heterossexual, portanto, a partir disso, podemos inferir que as injúrias seriam ainda mais massacrantes se os envolvidos estivessem em práticas homoeróticas. Em se tratando da visão da Igreja sobre as homossexualidades, Marcos relatou:

\begin{abstract}
no meio evangélico, é visto como problemas espirituais, como coisa errada, é colocado como se a pessoa não fosse ser salva, perdesse a salvação, até por causa da homossexualidade. É essa a ideia que é passada para todos os membros, né? (...) uma pessoa que estaria em pecado e não teria salvação.
\end{abstract}

Marcos afirmou que não conseguia vislumbrar para sua vida, naquele momento da entrevista, as etapas programadas e esperadas pela sociedade e difundidas pela instituição religiosa em que congregava, como se casar com uma mulher e ter filhos. Também expôs o atravessamento subjetivo das pregações homofóbicas em relação à autoaceitação da homossexualidade:

\begin{abstract}
Olha, quando eles falavam contra... eu até que eu concordava porque... assim... eu também era contra o que eu sentia. Então, o fato de eles não concordarem, eu também não concordava, então, eu era contra também. (...) eu achava que era um pensamento comum, normal. (...) Eu tentava mudar o pensamento, pensar em outra coisa, evitando sempre os pensamentos. (...) não tem como evitar a atração e o desejo, mas eu evitava ficar pensando naquilo, em fazer aquilo. (...) como é visto pela religião como algo errado, eu começava a fazer orações, você começa a procurar uma ajuda também na religião para poder evitar aquilo, eu fiz constantemente isso.
\end{abstract}

Diante disso, podemos problematizar que o encontro com o poder de Marcos no contexto religioso poderia levá-lo à seguinte escolha: interditar suas possibilidades e expressões subjetivas relacionadas a sua sexualidade ou fugir deste contexto em que não teria empoderamento suficiente para enfrentar as opressões. Foucault (2003) enfatiza que não existem relações de poder completamente triunfantes ou incontornáveis. Desse modo, assim como as relações de poder-saber produzem assujeitamento, também é fato que o poder não existe sem resistência, na forma de um ataque a uma possível estratégia de classificação e disciplinarização. A resistência, neste caso, é caracterizada pelo contrapoder, que pode ser analisado como uma ação afirmativa da vida por parte da pessoa que foi submetida ao poder, numa tentativa de questioná-lo ou evitar suas ameaças de dominação. Essa situação específica onde o poder é posto em um patamar crítico de questionamento é denominada por Foucault de "encontro com o poder".

Sobre os efeitos nocivos que o discurso religioso possui, Marcos disse:

Religião, que é uma coisa que eu presenciei bastante, eu sei que tem uma influência muito grande tanto na aceitação da pessoa homossexual e também tem uma influência muito grande sobre os familiares, né, que é um ponto de vista religioso, onde é que vai passar o ponto de vista para as pessoas, então, acabam ocorrendo problemas mesmo na hora da aceitação, ou acaba dificultando muito o relacionamento da pessoa com os familiares, devido esse fator, da posição das instituições religiosas enquanto a isso, né? Para mim, na minha história, foi uma coisa que pegou bastante, porque traz muito mal-estar, culpa, medo e dificuldade de aceitação, pois se usa o nome de Deus, que é muitas vezes em vão. (...) A Igreja usa de persuasão, de medo, dizendo que os homossexuais não herdarão o Reino dos Céus e esse tipo de coisa. Então, imagina alguém que fica em conflito com isso por ser homossexual e que acredita no Reino dos Céus e buscou fazer tudo certo para conseguir isso e perder isso por conta da homossexualidade? A cabeça da pessoa fica muito confusa. 
Após se distanciar da instituição religiosa e de começar a morar sozinho, Marcos adentrou o mundo gay, primeiramente com relações virtuais anônimas. Podemos dizer que Marcos representava um perfil de jovem homossexual, que se considera não-assumido e por isso estabelece relações virtuais por meio de dispositivos (de sexualidade) tecnológicos para se homossocializar.

No entanto, o fim do controle da instituição religiosa e a participação em dispositivos virtuais aumentaram o desejo de Marcos de ter contato presencial com outros homossexuais (relacionar-se afetivo-sexualmente). Assim, ele se permitiu conhecer os dispositivos de socialização de sexualidades LGBT+, como revelou:

\begin{abstract}
Foi no fato dos primeiros relacionamentos homossexuais e pelo fato de eu conseguir ver o todo, de ter uma visão mais esclarecida sobre o assunto... porque até então eu tinha uma visão que era errado, errado perante Deus, enfim, essa formação religiosa, então, a partir do momento que eu comecei a ter relacionamento homossexual e a conviver no meio, começar a conhecer mais o que que era, eu fui vendo também que não era aquilo que eu conhecia, eu fui conhecendo e vendo que, pelo contrário, é uma coisa tão normal quanto a pessoa se denominar heterossexual (ênfase na palavra). Foi a partir daí que eu comecei a me denominar homossexual.
\end{abstract}

Em se tratando das relações estabelecidas por homossexuais de modo virtual, fica evidente, nos trechos da narrativa de Marcos, que os dispositivos virtuais de homossocialização favorecem a produção de modos de subjetivação que propagam a hierarquização e as relações de poderes por meio das valorações de perfis dos usuários na rede virtual. Dessa maneira, tais dispositivos reproduzem os discursos da microfísica de poder existentes nos dispositivos de socialização de sexualidades LGBT+. Tal questão aparece também nas falas analisadas por André Luiz Coutinho (2020) ao analisar a busca por parceiros (homo)sexuais em "aplicativos de pegação" gays; ou na netnografia desenvolvida por Damião Rocha e Marcos Irondes Coelho (2018) nos mesmos aplicativos.

Quando instigado a falar sobre relações sexuais com outros homens, Marcos relatou como foi negociar as primeiras práticas sexuais:

\begin{abstract}
Em um relacionamento homossexual, uma das partes mais dificeis, tudo é muito dificil, mas a mais complicada é fazer sexo passivo, então eu acredito que como ele [Vinícius] sabia que é, eu não tinha me relacionado antes, ele não teve essa cobrança nesse nosso início de namoro, então aconteceu, a gente se conheceu e aconteceu naturalmente, a gente foi ficando e não houve uma negociação. (...) fui ativo com ele, mas eu acho que foi assim pelo fato de eu não ter tido essa experiência anteriormente, então ele achou..., ele não fez nenhuma cobrança de sexo, de que eu fosse passivo, $e$ eu também tinha uma certa, hum, não dificuldade, mas eu não conhecia, não sabia, então eu também... No início foi uma coisa também que eu não procurei.
\end{abstract}

A partir do coming out nos dispositivos de socialização de sexualidades LGBT+ foi que Marcos teve que se confrontar com seus valores pautados na criação religiosa, pois o modo de subjetivação advinda da instituição Igreja fez com que ele "se assustasse" e encarasse com estranheza as diversas formas de estilos de vida e expressões afetivo-sexuais, como, por exemplo, homens de mãos dadas e se beijando em um lugar público (mesmo sendo um lugar reservado): “... estranhei, achei estranho porque não estava dentro dos padrões que eu costumava ver". Ainda que o motivo para frequentar tais lugares fosse querer, nas palavras do entrevistado, “... um lugar onde respeitasse minha sexualidade e encontrasse outros homossexuais”, Marcos sentiu estranhamento, o que demonstra como os discursos morais e religiosos haviam atravessado sua produção de subjetividade.

Na pesquisa desenvolvida por Lopes (2010) com homossexuais masculinos em Cuiabá, que viviam uma relação de conjugalidade, a categoria "respeito", "respeitabilidade", "dar-se ao respeito" foi acionada diversas vezes nas narrativas dos entrevistados, que apontaram uma dinâmica de conhecimento/desconhecimento 
do segredo de suas homossexualidades e conjugalidades por familiares, amigos, vizinhos ou colegas de trabalho. A manipulação e a seleção dos possíveis portadores do segredo revelam a existência, no imaginário social e no contexto da religião, de uma infinidade de representações de caráter negativo, bem como do preconceito e da discriminação sobre as homossexualidades, que na fala de Marcos aparecem por um estranhamento e um embate com seus "valores" ao presenciar diversas formas de expressão afetivo-sexuais. É importante destacar, tal como aponta Eve Kosofsky Sedgwick (2007), que a "gramática do armário" não pode ser tomada como estruturada exclusivamente a partir da oposição assumido/nãoassumido, pois, mesmo as pessoas assumidamente gays estão de algum modo dentro do armário em relação a alguém que é importante para elas em algum nível. O sair do armário, tal como aponta a autora, envolve sempre um cálculo acerca de possíveis perdas e ganhos resultantes de tal "revelação".

Levando em consideração tais questões, Marcos definiu os dispositivos de socialização de sexualidades LGBT + como lugares para buscar amizades, conversar com pessoas LGBT+ e para encontrar parceiros afetivo-sexuais. Ele parecia estar interessado em vivenciar as relações de sociabilidades desses dispositivos e, dessa maneira, fazer com que esses relacionamentos se estendessem para além dos contornos delimitados dos estabelecimentos de frequência de grupos LGBT+. Antenado em seu tempo, o participante deu pistas de quais estabelecimentos, não necessariamente guetificados, podiam corresponder aos dispositivos de socialização de sexualidades LGBT+, citando os shoppings do município (praças de alimentações, áreas de recreação, cinemas) como lugares de flertes (CARRANO, 2002), uma vez que jovens, de maneira geral (e mais fortemente na experiência LGBT+) não possuem pontos de encontro específicos, não têm idade para frequentar lugares noturnos e vivenciam a visibilidade da sexualidade e o controle familiar.

Quando questionado sobre contextos que envolvem expressões de preconceito contra homossexuais, Marcos demonstrou certa confusão e não conseguiu responder com exatidão como observa esses acontecimentos sociais. De maneira geral, durante a entrevista, analisou-se que Marcos pouco conseguia discriminar relações e assujeitamento ao poder, uma vez que seu referencial de socialização em grupo lhe foi passado, em grande parte, pelos integrantes da instituição religiosa a qual fazia parte, ou seja, um referencial de desrespeito à privacidade e de práticas sociais homofóbicas. Isso é reiterado na seguinte fala do participante: "Vou cuidar da minha saúde, porque da minha vida já cuidam". Esses sistemas de opressão contribuem para que pessoas LGBT+ compreendam o preconceito como algo pessoal/individual e não coletivo, o que faz com que não se percebam como sujeitos de direitos.

Em um primeiro momento, ao tomar como referência lugares frequentados supostamente apenas por heterossexuais, Marcos inicialmente afirmou que não existe preconceito contra homossexuais nos dispositivos de socialização de sexualidades LGBT+:

Não há a presença do preconceito, né? A pessoa não vai ter preconceito nenhum pelo fato de você ser homossexual. (...) até existe o preconceito lá dentro, mas a discriminação não vai ser ao fato de você ser homossexual igual é em um lugar que só vai héteros. Porque o preconceito é, bom, algum tipo ou outro de preconceito sempre acaba tendo, né? Mas o preconceito maior, igual de um bar hétero, se saberem que você é gay, de te expulsarem ou correr o risco de apanhar, lá não tem.

Porém, durante a entrevista, na medida em que se buscava mais informações acerca das relações interpessoais, Marcos apontou, em seu discurso, percepções 
que revelaram uma dificuldade de autoaceitação e a construção hierárquica e de relações de poderes entre os próprios LGBT+:

\begin{abstract}
Eu digo preconceito em termos gerais, né? Às vezes, a própria pessoa acaba sendo preconceituosa por não se aceitar ou um tipo de grupo LGBT que não aceita outra pessoa, enfim, um preconceito sempre existe, né? [...] De homossexuais para homossexuais, porque existe o caso de homossexuais que tem preconceito por travesti, que não gosta, que tem um preconceito e é homossexual. Então, existe este preconceito nos bares, nas boates... no meio LGBT, no meio homossexual... então, neste meio também existe preconceito sim, não está livre do preconceito, não. Mas mesmo assim, é um ambiente que você consegue se relacionar. Dá para ir lá e num ter que não ser você, você pode relaxar um pouco mais. [...] pessoas que sofrem o preconceito percebem sim, é uma situação chata, porque elas olham e as pessoas estão olhando para ela e rindo, mas como o próprio LGBT aprende e tem que viver com a discriminação, né, então, eles acabam meio que contornando isso. [...] Em todo o momento o passivo é vítima de gozação, assim como o pobre e o afeminado. Mas nem sempre é só o nãoafeminado que ri do afeminado, tem afeminado que fica rindo do outro afeminado, achando que ele não é igual, achando que ele não é afeminado. [...] pelo que eu percebo, a todo momento, é um perfil mais valorizado é o mais próximo da imagem hétero, vamos dizer, o homem... o homossexual que não dá pinta, que as pessoas visivelmente não percebam que ele é gay, que é ... como se diz, que não é afeminado. Então, assim, uma das primeiras perguntas que sempre me fazem é exatamente isso: “Você é afeminado?". Então eu vejo isso, que já é um dos maiores preconceitos nos aplicativos, porque é a primeira coisa que a pessoa não quer relacionar com uma pessoa que seja muito afeminada, ou que esteja muito próximo da aparência feminina. Isso vale para relacionamentos e também para amizade, pois as pessoas não querem marcar encontro com afeminadas porque podem ser reconhecidos..., tipo, marcar de se conhecer no shopping com uma pessoa afeminada. As pessoas acham que é queimar o filme e rejeitam esse tipo de situação. Elas evitam isso.
\end{abstract}

Marcos indicou não conhecer saunas, pontos de pegação e dark rooms e confessou achar esses lugares perigosos e de pouco interesse. No entanto, ele frequentava bares toda semana e boates quinzenalmente. Argumentou que se sentia acolhido e pertencente a esses lugares e que não tinha nenhuma reclamação em relação a eles, pois neles havia a possibilidade de flertar sem receios e fazer amigos homossexuais. Além da socialização, revelou que estava procurando por um namorado, mas acreditava que a boate não era um lugar interessante para se conhecer um parceiro, uma vez que lá as pessoas se liberavam e "ferviam". Sobre isso, Marcos contou:

Na boate é um ambiente descontraído, você dança, você bebe, você conversa bastante, encontra pessoas, você se relaciona... Eu acredito que na boate, namoro não... comigo não aconteceu, não conheci ninguém que fosse lá que eu namorei, mas já fiquei com várias pessoas, tanto na boate e posteriormente à boate, depois, marcava de encontrar, mas nenhum desses relacionamentos acabei namorando. Mas tive vários relacionamentos. Vou também para me sentir bem em público com meus amigos que também são homossexuais. Então, a boate é um espaço que eu vou para me relacionar com outras pessoas, conhecer pessoas, ficar com pessoas.

O participante complementou dizendo que a boate, por ser um "lugar mais fechado", permitia que ele expressasse afetos em público (beijos, andar de mãos dadas, carinho, abraços, entre outros), fato que não ocorria no bar em que frequentava devido a presença de público heterossexual. Marcos diferenciou o bar da boate relatando que o primeiro era um estabelecimento onde as conversas e as relações de rosto aconteciam mais nitidamente e que o segundo era um lugar onde o contato erotizado era mais frequente e intenso.

Quando questionado sobre as práticas sociais LGBTfóbicas existentes nesses lugares de socialização entre os próprios LGBT+, o rapaz respondeu:

Existe o próprio preconceito dentro da própria boate, do próprio meio LGBT. Para mim é tranquilo, eu converso com todo mundo e não tenho problema com ninguém e nenhum grupo, em conversar com uma pessoa que seja travesti, com uma pessoa 
que... então, não tem... ou, às vezes, uma pessoa, um gay que é afeminado demais [...]. Sei que tem bastante sim, que hoje tem bastante desse tipo de discriminação, principalmente na internet, onde a pergunta mais feita é se a pessoa é afeminada. Existe esse preconceito sim, principalmente nos ambientes frequentados por homossexuais contra essas pessoas, ou por ser afeminadas ou serem travestis, pelo fato de as pessoas não quererem nem se relacionar com eles, né? Às vezes, na boate ou em um barzinho gay, ele vai e tenta ser seu amigo, mas lá fora, as pessoas não querem levar essa amizade para fora, para o dia a dia, fica um amigo de bar gay, até para essas pessoas que são afeminadas, que lembram, à vista da sociedade, são pessoas com características de homossexuais, então, seria uma forma de vincular a ideia das outras pessoas também serem homossexuais. [...] na realidade ele existe, é, pelo próprio fato de evitar, eu vejo que eles evitam a pessoa pelo fato dela ser travesti, pelo fato de ser afeminado, principalmente o gay que é muito preconceituoso em relação a isso. $\hat{E}$, acaba evitando, evita, ou tem alguns comentários, desde comentário para evitar o outro, ou até pela expressão quando o outro chega perto e você vê que as pessoas não gostam e acontece esse tipo de coisa. [...] tanto na boate quanto no meio social de modo geral, os mais valorizados, por existir um preconceito ainda muito grande, as pessoas ainda buscam as pessoas que são, mas que não parecem, que seja homossexual, mas que ele tenha um estereótipo parecido como se não fosse, que não desse pinta, ou pela aparência ou pela conversa, ou com o corpo definido, o mais próximo da imagem masculina possível, não que todos, mas que no geral se procura isso, estes os que se dão melhor no meio gay e na vida.

Essa fala ilustra como o discurso acerca das práticas sociais LGBTfóbicas favorece o posicionamento das sexualidades e dos gêneros cristalizados, naturalizados e presos às construções do determinismo biológico do corpo, não permitindo a transitoriedade das sexualidades, configurando identidades, papéis e funções delimitadas pelo masculino/feminino, macho/fêmea, entre outros (SCOTT, 1995: 72; LOURO, 2004: 72).

Os dispositivos de controle das sexualidades (BUTLER, 2003) apresentam uma ordem compulsória do sistema sexo-gênero, que regula e normatiza a produção de identidades de modo binário e naturalizante. As relações de gêneros e as sexualidades (práticas sexuais) são aspectos muito valorizados na cultura e nas relações de sociabilidades. Portanto, as práticas sociais homofóbicas exemplificadas acima, nas palavras de Marcos, sugerem que nos dispositivos de socialização ocorrem relações de poder assinaladas por práticas discursivas pautadas nos enunciados heterocentristas, machistas e viris, entre outros aspectos que formulam maneiras de hierarquizar os sujeitos que coabitam um mesmo dispositivo de socialização. Essas práticas não permitem novas inscrições dos gêneros (LOURO, 1999: 11), impedindo outras maneiras de existências e expressões singulares resistentes à normativa heterossexual.

Dessa forma, o preconceito contra as sexualidades e os gêneros advém do lugar em que homossexuais masculinos ditos afeminados, mulheres masculinizadas, travestis, entre outros, ocupam na hierarquia traçada pela heteronormatividade. Esses sujeitos estigmatizados pertencem à categorização dos "seres abjetos" (BUTLER, 1999), carregando em suas vivências as marcas de práticas sociais violentas em relação às suas existências e às suas identidades marginalizadas. De acordo com Sérgio Gomes da Silva (1999: 72-3):

\footnotetext{
a identidade de gênero e sexual, sugere um destino sem escolha ou renúncia, imposto e cobrado direta ou indiretamente pela sociedade em que vivemos, estabelecendo o poder normativo da masculinidade nos homens e da feminilidade nas mulheres. $\mathrm{Na}$ lógica classificatória das identidades de gênero e sexual em nossa cultura burguesa, capitalista, ocidental e patriarcalista, é sobretudo a heterossexualidade que ocupa, em ambos os sexos, o lugar de representante de sua essência identitária.
}

A hierarquia e as relações de poder produzem agrupamentos nos dispositivos de socialização de sexualidades LGBT+. Esses agrupamentos se apoderam de práticas coletivas e apresentam características em comum, podendo se originar do 
enfrentamento solidário da estigmatização ou para produzir um grupo que estabelece hierarquização sobre os demais. Os agrupamentos dentro de um dispositivo de socialização de sexualidades LGBT+ sugerem o embasamento das categorias de gêneros e das práticas sexuais, tornando as pessoas como que unicamente sujeitos sexuais e desconsiderando as multideterminações dos atores sociais advindas dos processos de singularização e de produções criativas e convergentes. A imagem erótica e as práticas sexuais parecem ser componentes de socialização poderosas em um dispositivo de socialização, em detrimento, por exemplo, de pessoas que tocam instrumentos musicais, fazem a mesma faculdade, que possuem os mesmos hobbies.

Acerca dos processos de estigmatização que transpassam as divisões de grupos que se estabelecem dentro dos dispositivos de socialização de sexualidades LGBT+, Marcos trouxe em sua fala a percepção da formação de grupos que se unem por características como classe social e econômica:

\begin{abstract}
Tem o caso de... das pessoas que moram lá no (bairro distante), que é um conjunto de vários bairros da cidade, que é afastado do centro. As pessoas se juntam porque vêm no mesmo ônibus, vivem no mesmo bairro e têm a mesma situação econômica. Às vezes, daí vem mais uma forma de preconceito, que falam que são as bichas pobres, que vêm de ônibus do (bairro distante), que elas têm que sair depois da novela das seis para poder conseguir chegar na boate antes da meia-noite para conseguir entrar com cortesia, isso na sexta. Como você sabe, na sexta, as pessoas dizem que vai o pessoal mais feio porque tem o free pass, a cortesia, e é o pessoal do (bairro distante), daí o pessoal fala que eles tomam café da manhã na boate para pegar o ônibus de manhãzinha porque não tem ônibus antes... falam isso tudo tirando sarro. Por exemplo, também, se uma pessoa efeminada entra no dark room, as pessoas comentam quando ela sai de lá que ela deve ter dado para todo mundo e se um cara que não é afeminado entra lá, as pessoas não falam nada, tipo ele foi lá não para dar para todo mundo, entendeu? Né? Acho que isso pode ser preconceito também, né?
\end{abstract}

No que tange a classificação e agrupamento por classe social e econômica, é importante salientar que esse fato foi possível de se analisar, pois, como disse Marcos:

\footnotetext{
Aqui na cidade em específico, né, é uma boate, que por ser única, então... não tem um ambiente, que vamos dizer assim, não existe um ambiente que seria frequentado por uma classe maior ou menor ou diferença de classes sociais. Então, é um ambiente frequentado desde a classe social mais baixa até de poder aquisitivo maior.
}

Durante a entrevista Marcos fez, o tempo todo, observações de práticas preconceituosas de outras pessoas. Todavia, quando questionado sobre militância LGBT+, o discurso heteronormativo evidenciado na busca da invisibilidade apareceu de maneira nítida quando o participante disse: "hoje eu não participaria de militância, pelo fato da imagem, de... de difundir minha sexualidade mesmo, ou mesmo medo da reação das pessoas que vão estar vendo, em frente isso". Como apontado anteriormente, a "gramática do armário" (SEDGWICK, 2007) é um processo problemático que envolve uma situação de perigo seja pelo risco de perda afetiva ou econômica, seja pela associação com outros riscos e medos, como: o de ser expulso de casa pelos pais; de perder o contato com os familiares; da violência (física ou simbólica); de não ser aceito pelos pais, familiares e amigos, entre outros. Marcos, assim como diversas pessoas LGBT+ do município onde foi realizado este estudo, não se envolvia politicamente e não possuía o desejo de participar de um movimento social LGBT+, tendo como argumento principal o receio da exposição. Deste modo, a participação em ONGs ou grupos LGBT+, para além da exposição da homossexualidade, poderia gerar um risco não só para Marcos, mas também para seus projetos de vida. 
Em se tratando de ONGs que trabalham com grupos LGBT+, Facchini (2005: 28-9) aponta que a construção cultural de uma identidade coletiva deve compreender a formação desse grupo como uma construção homogênea e com interesses em comum, constituído de sujeitos que fomentem uma "aliança política voltada para um determinado fim", portanto, que se perceba como fazendo parte daquele grupo. Sendo assim, a construção desse grupo passa pela "gramática do armário", uma vez que, para ingressar como integrante público, a pessoa precisa ponderar como isso afetará sua vida.

Em dado momento, Marcos admitiu que o incomodava um pouco o convívio com homossexuais afeminados e que acreditava que não é necessário ser afeminado para ser homossexual. Complementou dizendo que afetivamente não se interessa por pessoas afeminadas e se disse reticente em relação a homossexuais assumidos, uma vez que não realizou seu coming out. O participante parecia estar em um processo de enfrentamento dos modos de subjetivação a qual tinha sido submetido. A passagem pelas instituições massacrantes possivelmente deixou marcas fortes na história de vida de Marcos, porém, ele havia se proposto a conhecer novos estilos de existência e procurava compartilhar experiências com outras pessoas LGBT+.

Marcos se apresentava otimista em relação ao futuro, no que tangia sua vida afetivo-sexual. Sugeriu que poderia pautar sua vida em um modelo de conjugalidade de referência heterossexual, como se casar de papel passado para poder oferecer segurança e estabilidade ao parceiro, que dividiria com ele a moradia e outros aspectos da vida a dois.

Quando questionado sobre a experiência de ter falado sobre sua vida e revelado questões bastante íntimas, o participante respondeu:

\begin{abstract}
É, sempre a gente falar é complicado, porque vamos estar tratando de coisas de nossa vida, que muitas das vezes que você procura... que você até nem pensa. Você vive até sem refletir sobre alguns pontos, né? Foi dificil, porque em alguns pontos a gente teve dificuldades em estar falando, né, por ser algumas intimidades bem particulares, então, eu tive um pouco de dificuldade, mas no contexto geral, foi bom, também pelo fato de você estar falando assim, foi legal. Fiquei pensando várias coisas, meio tipo terapia, né? Tem que repensar muitas coisas da vida, da minha vida, da minha sexualidade e em falar e entender um pouco mais de mim a partir de suas perguntas.
\end{abstract}

Após a entrevista, Marcos me convidou para ir com ele a uma padaria e conveniência para tomar um lanche de fim de tarde. Questionou-me várias vezes se eu poderia emprestar as gravações para ele verificar a própria voz, pois acreditava que ela poderia ter um "tom meio afeminado em gravações”. Brinquei, dizendo que também não gostava de minha voz em gravações, mas o importante era o que tinha sido dito e quando possível passaria uma cópia impressa da entrevista para ele. Durante nossas interações pós-entrevista, Marcos revelou, de maneira mais descontraída, histórias irreverentes de encontros casuais e do desejo de encontrar um namorado para a vida toda.

\title{
Considerações finais
}

A narrativa de história de vida se constituiu como um potente processo metodológico para propor a análise de condições de vidas interseccionadas por marcadores sociais de diferença, tais como sexualidade, orientação sexual, identidade de gênero, classe social e econômica, geração (idade), raça e etnia, cultura e territorialidades, corporalidades, entre outros.

Primeiramente, evidenciamos que existem diversos modos para "montar" e analisar uma narrativa, que pode ser elaborada a partir de um procedimento de 
entrevista linear e cronológica, ou que pode desviar deste caminho e produzir "pinguelas" para explorar temáticas, problematizações, experiências, sensações, tensões e contradições, tornando-se uma "colcha de retalhos colorida" que se (re)constrói em vários momentos em um processo em que apenas finalizarmos a escrita, mas nunca a história.

Em muitos momentos observamos essas tensões como receios, ansiedades, enfrentamentos, possibilidades e produções, uma vez que falar de si constitui a própria pessoa por meio de produções de pensamentos, ora divergentes, ora convergentes. Essas tensões discursivas analisadas por meio de difrações e digressões teóricas propõem a análise das instituições sociais, que funcionam como mecanismos estratégicos e engendrados da hierarquização e das relações de poder binarizantes entre os sujeitos, que organizam práticas sociais cotidianas, estilos de vida e modos de subjetivação de assujeitamento.

Nos trechos e temáticas trazidos pela narrativa de Marcos, podemos analisar as instituições como sendo "dispositivos de poder" que controlam e disciplinarizam as existências e os desejos a favor das estratégias políticas de normatização social, punindo aqueles que ousam se desviar do caminho do adestramento.

Em se tratando de modos de subjetivação em contextos interioranos, encontramos que os mecanismos de controle se apresentam muito mais "personalizados" e "identificáveis", produzindo "monstros" sociais, cuja condição abjeta faz com que sejam execrados do convívio dos "homens de bem" e dos "homens de bens".

Em específico aos recortes narrativos analisados, a territorialidade interiorana, a condição de grau de instrução (nível superior de ensino e cultural), a condição financeira, o estilo de vida e a geração são elementos importantes para a formação de pares e para a socialização. Estes podem ser compreendidos como elementos que se interseccionam para a produção de relações interpessoais específicas, formas articuladas de opressão e privilégio, formas contextuais de ser e estar no mundo e, com isso, uma subjetividade específica e um sujeito particular, tal como apontaram Avtar Brad (2006) e Lopes (2016).

Quanto menos destaque e status as pessoas apresentam em relação a esses marcadores sociais, mais desprivilegiadas e vulneráveis se tornam, ficando mais frequentemente expostas às práticas sociais violentas. Nesse contexto, o sofrimento psíquico e subjetivo ocasionado pelo enfrentamento de situações preconceituosas e de rejeição afeta e é afetado mutuamente pela dificuldade de empregabilidade e pela preterição em relacionamentos afetivo-sexuais e de socialização, o que pode inclusive culminar em suicídio.

Podemos analisar, de acordo com Márcio A. N. Nascimento (2007), Lopes (2009, 2010) e Nascimento e Thiago C. Sanches (2020), que em contextos interioranos o poder interditivo é muito mais evidente, uma vez que a construção sócio-histórico-político e cultural da moralidade apresenta uma tendência a permanecer mais resistente a novos estilos de vida e formas de pensar e agir. Em relação aos recortes da narrativa de Marcos em que o entrevistado apresenta uma rejeição ao "afeminado" e ao "estilo LGBT+ de vida", analisamos que no contexto familiar, religioso e interiorano se torna mais difícil produzir outros modos de subjetivação sem a experimentação e a aproximação com outras estilísticas de existências singulares e/ou dissidentes, torna-se mais difícil sair da lógica dos dispositivos das sexualidades, uma vez que somos subjetivados para sermos desejosos de normas.

Apresentar-se como LGBT+ na atualidade não garante a ruptura com a (re)produção desse dispositivo de normatização, uma vez que para escapar dos 
mecanismos de disciplinarização é necessário deserotizar as relações de poder e favorecer as relações baseadas em uma perspectiva do cuidado de si e do prazer (FOUCAULT, 1988). A subversão possível para Marcos poderia ser (re)descobrir outras maneiras de busca de prazeres, de existências, sociabilidades, afetos, sensações, experiências e, partindo de uma ética da vida, não se cristalizar apenas nos desejos normativos e redutivos da vida em expansão.

Recebido em 18 de abril de 2021. Aceito em 30 de maio de 2021.

\section{Referências}

ALENCAR, Venan L. de Oliveira. Estresse de minoria em narrativas de vida de homens gays no youtube. REBEH - Revista Brasileira de Estudos da Homocultura, 3 (11): 101-118, 2020.

BRAH, Avtar. Diferença, diversidade, diferenciação. Cadernos Pagu, 26: 329376, 2009.

BUTLER, Judith. "Corpos que pesam: sobre os limites discursivos do 'sexo". In: LOURO, Guacira Lopes (org.). O Corpo Educado: pedagogias da sexualidade. Belo Horizonte: Autêntica, 1999. pp. 153-172.

BUTLER, Judith. Problemas de gênero: feminismo e subversão da identidade. Rio de Janeiro: Civilização Brasileira, 2003.

CARRANO, Paulo César Rodrigues. Os jovens e a cidade: identidade e práticas culturais em Angra de tantos reis e rainhas. Rio de Janeiro: Relume-Dumará/ FAPERJ, 2002.

COUTINHO, André Luiz. Desejo e "aplicativos de pegação" gays: A busca de parceiros (homo)sexuais baseada em imagens heterossexualizadas. $R E B E H-R e-$ vista Brasileira de Estudos da Homocultura, 3 (10): 59-72, 2020.

FACCHINI, Regina. Sopa de Letrinhas? Movimento homossexual e produção de identidades coletivas nos anos 90. Rio de Janeiro: Garamond, 2005.

FONSECA, Claudia. Quando cada caso NÃO é um caso: pesquisa etnográfica e educação. Revista Brasileira de Educação, 10 (1): 58-78, 1999.

FOUCAULT, Michel. Vigiar e punir: nascimento da prisão. Trad. Raquel Ramalhete. 19. ed., Petrópolis: Vozes, 1987.

FOUCAULT, Michel. História da sexualidade 2: o uso dos prazeres. Rio de Janeiro: Edições Graal, 1988. 
FOUCAULT, Michel. "A vida dos homens infames". In: FOUCAULT, Michel. Estratégia, poder-saber (Ditos e Escritos IV). Rio de Janeiro: Forense Universitária, 2003. pp. 203-222.

FOUCAULT, Michel. História da sexualidade 1: a vontade de saber. Rio de Janeiro: Edições Graal, 2005.

GOFFMAN, Erving. Estigma: notas sobre a manipulação da identidade deteriorada. 4. ed., Rio de Janeiro: LTC, 1988.

LOPES, Moisés. "Casar e dar-se ao respeito". Conjugalidade entre homossexuais masculinos em Cuiabá. In: HEILBORN, M. L. et al. (orgs.). Sexualidade, Saúde e Reprodução. Rio de Janeiro: FGV, 2009. pp. 489-508.

LOPES, Moisés. “Eu, você e eles: ou a difícil arte de se dançar a três”: Conversação e caracterização do self em uma entrevista. $R @ u$ - Revista de Antropologia Social do PPGAS-UFSCar, 2 (2): 188-206, 2010.

LOPES, Moisés. Algumas observações sobre as homossexualidades em "contextos interioranos": Lançando questões de "fora dos centros". Amazônica - Revista de Antropologia, 8 (1): 24-37, 2016.

LOURO, Guacira Lopes. "Pedagogias da sexualidade”. In: LOURO, Guacira Lopes (org.). O corpo educado: pedagogias da sexualidade. Belo Horizonte: Autêntica, 1999.

LOURO, Guacira Lopes. Um corpo estranho: ensaios sobre sexualidade e teoria queer. Belo Horizonte: Autêntica, 2004.

NASCIMENTO, Márcio Alessandro Neman do. Homossexualidades e homossociabilidades: hierarquização e relações de poder entre homossexuais masculinos que frequentam dispositivos de socialização de sexualidades GLBTTT. Dissertação (Mestrado em Psicologia), Faculdade de Ciências e Letras de Assis, Universidade Estadual Paulista "Júlio de Mesquita Filho”, 2007.

NASCIMENTO, Márcio A. N. do; SANCHES, Thiago C. Narrando a história de quem conta a própria história: o "era uma vez..." como processo metodológico. In: LEMOS, Flávia Cristina Silveira (org.). Pesquisar com as psicologias: artesanais e artifícios. Curitiba: CRV, 2020. pp. 387-403.

ROCHA, Damião e COELHO, Marcos Irondes. 'Manda Nudes': Os crush gays nos aplicativos fast foda de relacionamentos. REBEH - Revista Brasileira de Estudos da Homocultura, 1 (4): 5-17, 2018

SCOTT, Joan W. Gênero: uma categoria útil de análise histórica. Educação e Realidade, 20 (2), 1995.

SEDGWICK, Eve Kosofsky. A epistemologia do armário. Cadernos Pagu, 28: 19$54,2007$.

SILVA, Sérgio Gomes da. O conflito identitário: sexo e gênero na constituição das identidades. Revista Brasileira de Sexualidade Humana, 10: 70-85, 1999. 


\section{A
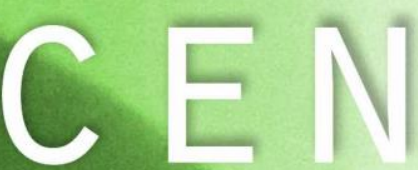

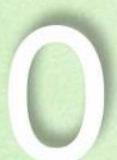

REVISTA DE ANTROPOLOGIA DO CENTRO-OESTE

ISSN: 2358,5583

NOVO QUALIS PERIÓDICOS DA CAPES CONFIRMA A ACENO NOS ESTRATOS SUPERIORES

2.

nova avaliação da Capes sobre as revistas científicas dos programas de pós-graduação
brasileiros, divulgada neste ano de 2021, confirmou

a Aceno numa nova classificação, $\mathbf{A} 3$, conquistando espaço entre periódicos de estratos superiores.

Temos certeza que isso só foi possível por conta do apoio que a Aceno tem recebido da comunidade acadêmica desde que começou a ser publicada em 2014.

Nós, do Programa de Pós-Graduação em Antropologia Social da UFMT agradecemos a todos os autores, pareceristas, leitores e editores pela colaboração nesses 7 anos e esperamos continuar a contar com a participação de todos, $\mathrm{e}$ crescendo ainda mais. 